\title{
Fatal neonatal meningitis due to Group B streptococci
}

\author{
B. Chattopadhyay \\ M.B.B.S., D.C.P., M.R.C.Path. \\ Department of Bacteriology, Queen Mary's Hospital, Roehampton, London
}

\begin{abstract}
Summary
A case of fatal neonatal meningitis due to Group B $\beta$-haemolytic Streptococcus is described. Early diagnosis and institution of vigorous antibiotic therapy were of no avail. Although the mortality rate is very high in comparison to many other neonatal bacterial infections reported so far, it is difficult to explain the fact that there are so few references to it as a pathogen in the British literature.

\section{Introduction}

The frequency with which Group B $\beta$-haemolytic Streptococcus is implicated as a neonatal pathogen in the American literature (Nyhan and Fousek, 1958; Hood, Janney and Dameron, 1961; Eickhoff et al., 1964; Maher and Irwin, 1966; Franciosi, Knostman and Zimmerman, 1973; Barton, Feigin and Lins, 1973; Baker et al., 1973) presents a striking contrast to the situation that exists in the United Kingdom, where this organism has only rarely been considered as a cause of morbidity or mortality (Jones and Howells, 1968; Rogers, 1970; Harper, 1971). Although definite evidence is lacking, it seems that many nursery units in the U.S.A. have been experiencing increased incidence of disease caused by this group of organisms (McCracken, 1973).
\end{abstract}

\section{Case report}

A 17-year-old primipara was admitted to the maternity ward with mild pre-eclampsia. Her labour was normal except that she was slightly pyrexial. She delivered a healthy male infant at $6.00 \mathrm{a} . \mathrm{m}$.; his weight was $2.9 \mathrm{~kg}$, Apgar score 4 at $1 \mathrm{~min}$ and 10 at $5 \mathrm{~min}$. A few hours after birth, at about 10.00 a.m., the infant suddenly developed grunting respirations and tachycardia with episodes of cyanosis. On examination, birth trauma or congenital malformations were not apparent. Although the baby appeared to be slightly

Correspondence: Consultant Microbiologist, Whipps Cross Hospital, Director, Public Health Laboratory, Leytonstone, London E11. irritable, there was no pyrexia. No other abnormalities could be detected in any other system including both the cardiovascular and the central nervous systems. At 11.45 a.m. $60 \% \mathrm{O}_{2}$ air mixture and $10 \%$ dextrose $8 \mathrm{ml} / \mathrm{hr}$ with $8.4 \%$ sodium bicarbonate $3 \mathrm{ml} / \mathrm{hr}$ i.v. were started. At 12.00 noon, penicillin $250,000 \mathrm{u}$ and kanamycin $22.5 \mathrm{mg}$ were given slowly, i.v. with $4 \mathrm{mg}$ of prednisolone. At the same time, after a lumbar puncture, 10,000 u of penicillin and $1 \mathrm{mg}$ of gentamicin were injected intrathecally. As the cerebrospinal fluid was cloudy and as meningitis in a neonate may be due to a variety of Gram-negative bacteria including Pseudomonas aeruginosa (Garrod, Lambert and O'Grady, 1973) it was thought wise to instil gentamicin. At 3.30 p.m. there was no change in the infant's condition and at 4.00 p.m. he suddenly collapsed. He was intubated for $20 \mathrm{~min}$ but no oxygenation of the tissues could be achieved. Intracardiac injection of adrenalin $0.1 \mathrm{ml}$ of $1 / 1000$ and cardiac massage were of no avail. At 4.30 p.m. all attempts at resuscitation were stopped.

\section{Investigations}

Infant

Blood glucose, $50 \mathrm{mg} / 100 \mathrm{ml}$; blood urea, $18 \mathrm{mg} /$ $100 \mathrm{ml}$.

Blood gases: $\mathrm{pH}, 7 \cdot 1 ; \mathrm{pCO}_{2}, 68 \mathrm{mmHg}$; standard bicarbonate, $16 \mathrm{mEq} / 1$; actual bicarbonate, $20 \mathrm{mEq} / 1$; base deficit, $10 \mathrm{mEq} / 1$.

Plasma electrolytes: $\mathrm{Na}, 143 \mathrm{mEq} / 1 ; \mathrm{K}, 6.3 \mathrm{mEq} / \mathrm{l}$; respiration, $54 / \mathrm{min}$; rectal temperature, $36.3^{\circ} \mathrm{C}$; haemoglobin, $11.8 \mathrm{gm} \%$; ESR, $63 \mathrm{~mm} / \mathrm{hr}$; white blood cells, $24928 / \mathrm{mm}^{3}$; polymorphs, $93 \%$; lymphocytes, $3 \%$; monocytes, $2 \%$; eosinophils, $1 \%$; basophils; $1 \%$.

Cerebrospinal fluid: appearance, cloudy; white blood cells, $2188 / \mathrm{mm}^{3}$; polymorphs, $91 \%$; lymphocytes, $9 \%$; red blood cells, $5 / \mathrm{mm}^{3}$; Gram-stained film, Gram-positive cocci in chains.

Nose, throat, rectal swabs, blood cultures and CSF were sent for bacteriological examination. All of them 
showed Gram-positive cocci in chains and grew $\beta$ haemolytic streptococci Group B. The growth was profuse and pure.

\section{Mother}

Haemoglobin, $13.7 \mathrm{gm} \%$; blood group, $\mathrm{A}, \mathrm{Rh}+$; pregnancy: mild pre-eclampsia, B.P. $130 / 100$, no oedema. She was slightly pyrexial in labour and two high vaginal swabs were sent for routine bacteriological investigations. The Gram-stained film showed Gram-positive cocci in chains with few lactobacilli; $\beta$-haemolytic streptococci Group B were also cultured. She was treated with penicillin, and after treatment the high vaginal swab was clear. Her puerperium was uneventful except that she was treated with hydralazine for hypertension and with nitrazepam for sedation.

\section{Method of isolation and sensitivity testing}

The streptococci were grouped by the acid extraction/precipitation method (Lancefield, 1933). All the strains belonged to $\beta$-haemolytic streptococci Group $B$, and were of the same antigenic type, subtype B II. They were sensitive to penicillin $(6 \mu \mathrm{g})$, erythromycin $(10 \mu \mathrm{g})$, and tetracycline $(10 \mu \mathrm{g})$; moderately resistant to gentamicin $(10 \mu \mathrm{g})$, resistant to streptomycin (10 $\mu \mathrm{g})$ and kanamycin $(5 \mu \mathrm{g})$ by the disc diffusion test on $5 \%$ lysed blood agar plates.

\section{Post-mortem examination of infant}

Macroscopically, the brain was swollen and its vessels markedly engorged. A moderate amount of exudate was present which filled the sulci and obscured the gyri. The cisterns were also filled to some extent. Microscopically, the exudate showed extensive neutrophilic infiltration. The Gram-stained film revealed free and phagocytosed Gram-positive cocci in small chains. There was thrombophlebitis with cortical and subcortical haemorrhagic infarcts. The spleen was large, soft and flabby and there was congestion of the red pulp. Some of the lymph nodes were slightly increased in size and their sinuses were full of polymorphonuclear leucocytes.

The lungs were congested and oedematous and there was evidence of peritonitis and acute bacterial endocarditis.

Reticular elements of the bone marrow and the liver were hyperplastic and an increased number of leucocytes were seen in blood vessels.

\section{Discussion}

In 1958, the first cases of neonatal meningitis due to Group B streptococci were reported by Nyhan and Fousek (1958) followed by Hood et al. in 1961; Mannik, Barringer and Stokes in 1962; Eickhoff et al. in 1964; Winterbauer, Fortune and Eickhoff in 1966 and Butter and de Moor in 1967. Recent epidemiological studies in the U.S.A. revealed an incidence of two cases of infection and a mortality rate of $1 \%$ live births, and in a series of twenty-eight infected infants, seventeen died (Franciosi et al., 1973). Group B $\beta$-haemolytic streptococci are the commonest Gram-positive organisms causing meningitis during the first 3 months of life, and rank second only to Escherichia coli according to Barton et al. (1973); in their survey of eleven patients, two died. Of thirty-three infants with meningitis due to Group B B-haemolytic streptococci evaluated by Baker et al. (1973), ten died, giving an overall mortality rate of $30 \%$.

The British literature records only three reports so far: Jones and Howells (1968) reported two cases of meningitis of whom one died; Rogers (1970) recorded fourteen cases of neonatal sepsis, of whom five were stillborn and the other nine died within a few hours to a few days of birth; Harper (1971) reported only one case of meningitis in which the infant survived, most probably owing to the early institution of vigorous antibiotic therapy. All these neonatal infections were usually associated with a very high mortality rate (Fig. 1).

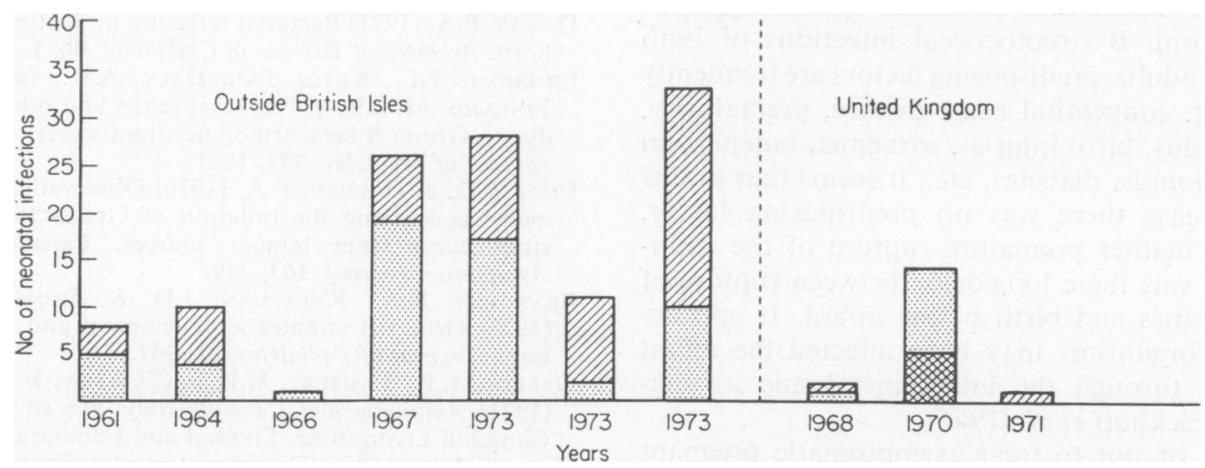

FIG. 1. Deaths in neonates due to Group B $\beta$-haemolytic streptococci. neonatal death. 
This organism can be recovered from cervical, vaginal, anal and amniotic fluid cultures of asymptomatic women during pregnancy, from nursery personnel and also from neonates after colonization (Franciosi et al., 1973; Baker et al., 1973; Baker and Barrett, 1973; Bergqvist et al., 1971; Davies, 1971). The majority of neonates, with or without meningitis probably acquire the organism from the birth canal of the mother either pre- or intranatally or from nursery personnel (MacKnight et al., 1969). Even infants delivered by Caesarian section with intact membranes may be acutely septic (Eickhoff et al., 1964; Hood et al., 1961; Keitel et al., 1962; Finn and Holden, 1970).

Group B $\beta$-haemolytic streptococci are usually typed as B Ia, B Ib, B Ic, B II or B III (Lancefield, 1933; Wilkinson and Eagon, 1971). The pattern and severity of Group B disease appears to be type related. Two distinct clinical syndromes have been described in neonates. The early septicaemic syndrome is usually associated with B I subtype. Case fatality can be as high as $100 \%$ and the majority of them die within 24-48 hr. The delayed meningitic form is caused by Group B III subtypes. The prognosis is considerably better and case fatality rate can reach $40 \%$.

Cellular and humoral responses of neonates to $\beta$ haemolytic streptococcal challenge have also been studied (Klesius, Mathews and Krushak, 1973; Zimmerman and Hill, 1969; Quinn and Lowry, 1967). It seems that three components are associated with sepsis: B Ia plasma factor; phagocytic activity; type specific agglutinins. Fatal acute sepsis from Group B Ia organism is apparently due to the absence of the immune components in most newborn infants.

Here in Britain, the paucity of reports of Group B $\beta$-haemolytic streptococcal infections may be due to the failure of some workers to identify correctly the organism in a busy diagnostic laboratory, or there may be a lower natural frequency of this organism here than in the U.S.A.

Although Butter and de Moor (1967) suggested that in Group B streptococcal infections of both infants and adults, predisposing factors are frequently present, e.g. congentital heart disease, prematurity, hydrocephalus, birth injuries, toxaemia, antepartum chorioamnionitis, diabetes, etc., it seems that in this particular case there was no predisposing factor. There was neither premature rupture of the membranes nor was there long delay between rupture of the membranes and birth of the infant. It appears that these organisms may have infected the infant by passing through the intact membrane as suggested by Eickhoff et al. (1964).

Whether or not to treat asymptomatic pregnant carriers in order to decrease the frequency of this fulminating neonatal infection remains a debatable point. A high vaginal swab at 32 weeks of gestation would detect an asymptomatic carrier and would allow adequate time to eradicate the organism before delivery (Franciosi et al., 1973). On the other hand, the high incidence of colonization among parturients and neonates compared with the relatively low attack rate for proved neonatal infections $(2 \cdot 9 / 1000)$ would seem to make the antibiotic prophylaxis rather impractical (Baker et al., 1973). Although it seems logical that after the birth of the infant the application of prompt and appropriate therapy may modify the course of the disease, in this particular instance it was unsuccessful. These findings emphasize once more that Group B $\beta$-haemolytic streptococci very easily cause infections in the newborn; these infections occur probably more frequently in Britain than the published reports would suggest, and they are usually associated with very high mortality.

\section{Acknowledgments}

I am greatly indebted to the Streptococcal Reference Laboratory, Colindale, for typing these strains, and to the Maternity Department of our hospital for allowing me to publish clinical details of this case.

I am also grateful to Mrs D. Chalmers for her secretarial help.

\section{References}

Baker, C.J., Barrett, F.F., Gordon, R.C. \& Yow, M.D. (1973) Suppurative meningitis due to streptococci of Lancefield Group B: A study of 33 infants. Journal of Pediatrics, 82, 724.

BAKER, C.J. \& BARRETT, F.F. (1973) Transmission of Group B streptococci among parturient women and their neonates. Journal of Pediatrics, 83, 919.

Barton, L.L., Feigin, R.D. \& Lins, R. (1973) Group B beta-hemolytic streptococcal meningitis in infants. Journal of Pediatrics, 82, 719.

Bergqvist, G., Hurrell, B., Malmborg, A.S., Rylander, M. \& TUNelL, R. (1971) Neonatal infections caused by Group B streptococci. Scandinavian Journal of Infectious Diseases, 3, 157.

ButTer, M.N.W. \& DE Moor, C.E. (1967) Streptococcus agalactiae as a cause of meningitis in the newborn, and of bacteraemia in adults. Antonie van Leeuwenhoek. Nederlandschtijdschrift voor hygiene, microbiologie en serologie, 33, 439.

DAvies, P.A. (1971) Bacterial infection in the foetus and new born. Archives of Disease in Childhood, 46, 1.

Eickhoff, T.C., Klein, J.O., Daly, A.K., Ingall, D. \& Finland, M. (1964). Neonatal sepsis and other infections due to Group B beta-hemolytic streptococci. New England Journal of Medicine, 271, 1221.

FINN, P.D. \& Holden, F.A. (1970) Observations and comments concerning the isolation of Group B $\beta$-hemolytic streptococci from human sources. Canadian Medical Association Journal, 103, 249.

Franciosi, R.A., Knostman, J.D. \& Zimmerman, R.A. (1973) Group B streptococcal neonatal and infant infections. Journal of Pediatrics, 82, 707.

Garrod, L.P., LAMBERT, H.P. \& O'Grady, F.W. (Editors) (1973) Antibiotic and Chemotherapy. 4th edition, p. 347. Churchill Livingstone, London and Edinburgh.

HARPER, I.A. (1971). The importance of Group B streptococci as human pathogens in the British Isles. Journal of Clinical Pathology, 24, 438. 
Hood, M., Janney, A. \& Dameron, G. (1961) Beta-hemolytic streptococcus Group B associated with problems of the perinatal period. American Journal of Obstetrics and Gynecology, 82, 809.

Jones, H. Everley \& Howells, C.H.L. (1968) Neonatal meningitis due to Streptococcus agalactiae. Postgraduate Medical Journal, 44, 549.

Keitel, H.G., Hananian, J., Ting, R., Prince, L.N. \& Randall, E. (1962) Meningitis in the newborn infant, Journal of Pediatrics, 61, 39.

Klesius, P.H., Mathews, J.H. \& KRushak, D.H. (1973) Cellular and humoral immune response to Group B streptococci. Journal of Pediatrics, 83, 926.

LANCEFIELD, R.C. (1933) A seriological differentiation of human and other groups of hemolytic streptococci. Journal of Experimental Medicine, 57, 571.

MacKnight, J.F., Ellis, P.J., Jensen, K.A. \& Franz, B. (1969) Group B streptococci in neonatal deaths. Applied Microbiology. 17, 926.

McCracken, G.H. (1973) Group B streptococci: The new challenge in neonatal infections. Journal of Pediatrics 82, 703.
Maher, E. \& IRWIN, R.C. (1966) Group B streptococcal infection in infancy: A case report and review. Pediatrics, 38, 659.

MaNnik, M., Barringer, J.R. \& Stokes, JosePh, III (1962) Infections due to Group B beta-hemolytic streptococci: report of three cases and review of the literature. New England Journal of Medicine, 266, 910.

NyHAN, W.L. \& FouseK, M.D. (1958) Septicemia of the newborn. Pediatrics, 22, 268.

QuINN, R.W. \& LowRY, P.N. (1967) Streptococcal M protein antibodies acquired at birth. Pediatrics, 39, 778.

ROGERS, K.B. (1970) Neonatal meningitis and pneumonia due to Lancefield Group B streptococci. Archives of Disease in Childhood, 45, 147.

Wilkinson, H.W. \& EAgon, R.G. (1971) Type specific antigens of Group B type Ic streptococci. Infection and Immunity, 4, 596.

Winterbauer, R.H., Fortune, R. \& Eickhoff, T.C. (1966) Unusual occurrence of neonatal meningitis due to Group $B$ beta-haemolytic streptococci. Paediatrics, 38, 661 .

Zimmerman, R.A. \& Hill, H.R. (1969) Placental transfer of Group A type-specific streptococcal antibody. Paediatrics, 43, 809 .

\title{
Excavating pulmonary metastases in carcinoma of the cervix
}

\author{
M. G. KirubaKaran \\ M.D.
}

\author{
B. M. Pulimood \\ F.R.C.P.
}

\author{
D. RAY \\ M.R.C.P.
}

\section{Christian Medical College and Hospital, Vellore-632004, South India}

\begin{abstract}
Summary
A case of excavating pulmonary metastases from carcinoma of the cervix is described. The secondary tumour had appeared nearly 4 years after apparent 'cure' of the primary lesion by radiotherapy. The diagnosis is discussed.
\end{abstract}

\section{Introduction}

Metastatic carcinoma is often not seriously considered in the differential diagnosis of multiple, thin walled cavitary lesions in the lungs. Though relatively rare, in the absence of predisposing causes, such lesions are more apt to be caused by metastatic carcinoma than by fungal diseases (Le May and Piro, 1965). Dodd and Boyle in 1961 reported sixteen cases of excavating pulmonary secondaries and Le May and Piro in 1965 collected a total of sixty-three cases from the world medical literature and added nine cases of their own. Since then a few more similar cases have been reported by different authors (Carleson, Delclos and Fletcher, 1967; Chawla and Bery, 1967; Narain, 1972). Most of these cases had their primary lesions in the head and neck regions while only a few (nine cases) had cancer of the cervix as the primary site (Narain, 1972). This report is of a case having excavating secondaries in the lungs, from cervical carcinoma treated successfully 4 years earlier.

\section{Case report}

A 37-year-old housewife was diagnosed as having squamous cell carcinoma of the cervix stage II B, confirmed by biopsy, for which she received curative radical radiotherapy. She was symptom-free until 3 months before admission to hospital 4 years later when she developed a non-productive cough. At the time of admission, physical examination revealed a healthy woman with the only positive finding of slightly reduced breath sounds in the right interscapular area. Careful examination including pelvic examination failed to reveal any evidence of active or residual disease elsewhere. The chest X-ray showed a large cystic lesion in the right upper lobe with air-fluid level and a similar, smaller lesion in the left lower lobe (Fig. 1). Repeated sputum examinations and cultures 